\title{
Fas gene promoter polymorphisms in primary Sjögren's syndrome
}

\author{
C G Mullighan, S Heatley, S Lester, M Rischmueller, T P Gordon, P G Bardy
}

\begin{abstract}
Background: Fas mediated apoptosis may be important in the pathogenesis of primary Sïgren's syndrome (pSS).

Objective: To examine genetic variation in the promoter region of the Fas gene in pSS.

Methods: Two single nucleotide polymorphisms at positions $-1377(\mathrm{G} / \mathrm{A})$ and -670 (G/A) in the Fas gene promoter were genotyped by PCR-SSP in 101 patients with pSS and 108 Caucasoid controls.

Results: No significant differences in allele or genotype frequencies were detected between the patients with pSS and controls. However, significant associations were observed with Ro/La autoantibody negative patients, who display milder and later onset disease. The $-670 \mathrm{~A}$ allele was more frequent in Ro/La autoantibody negative patients than in Ro/La autoantibody positive patients $(p=0.04)$.

Conclusion: This study does not confirm an earlier report of an association between pSS and the Fas promoter -670G allele. However, the results suggest that genetically determined variability in Fas expression may modulate Ro/La autoantibody responses in patients with pSS.
\end{abstract}

$\mathrm{P}$ rimary Sjögren's syndrome (pSS) is a systemic autoimmune disease characterised by lymphocytic infiltration and failure of salivary and lachrymal exocrine glands. The cardinal symptoms of pSS are severe dryness of the eyes and mouth (sicca), and various extraglandular features are also frequently seen. The pathogenesis of pSS is not understood, but genetic, hormonal, and infectious factors have all been implicated. Diagnosis of pSS is aided by the finding in most patients of circulating autoantibodies specific for the intracellular Ro/La ribonucleoproteins, although a pathogenic role for these autoantibodies has not been demonstrated. Ro/La autoantibody subsets in pSS are associated with distinct clinical and genetic profiles. ${ }^{12}$

Apoptosis, or programmed cell death, is an important mechanism used to delete autoreactive lymphocytes and may be a key factor in the development of autoimmunity. ${ }^{3}$ MRL/ lpr mice, characterised by a mutation of the gene encoding Fas, a mediator of apoptosis, exhibit pathological abnormalities in their salivary glands similar to pSS. ${ }^{4}$ In pSS, observations of increased expression of Fas, Fas ligand (FasL), and increased apoptosis in salivary gland epithelial cells have led to the proposal that abnormal apoptosis in exocrine glands may play a part in the observed exocrine gland destruction, ${ }^{5}$ although this remains controversial. ${ }^{6}$ Redistribution of the normally intracellular Ro and La autoantigens to surface membrane blebs on apoptotic cells has recently been demonstrated, ${ }^{7}$ a process by which these autoantigens may be accessible to the immune system. It is therefore conceivable that apoptosis may underlie the induction and facilitation of Ro/La autoantibody responses in pSS.
Two common single nucleotide polymorphisms in the promoter region of the Fas gene have been identified: -1377 $\mathrm{G} \rightarrow \mathrm{A}$ and $-670 \quad \mathrm{~A} \rightarrow \mathrm{G} .{ }^{8}$ The biological effects of these polymorphisms have not been fully elucidated, but it is possible that they are of functional significance, as the Fas -1377 polymorphism occurs at the consensus binding sequence of the transcription factor SP-1 in the silencer region, and the -670 polymorphism occurs at the consensus sequence of the nuclear transcription element GAS (gamma interferon activation site) in the enhancer region.

We suggested that genetic variation in the promoter region of the Fas gene might influence apoptosis and thus the pathogenesis of pSS and Ro/La humoral autoimmunity. To examine this hypothesis, the two polymorphisms in the Fas promoter were genotyped in a cohort of patients with pSS and a group of ethnically matched Caucasoid controls.

\section{PATIENTS AND METHODS}

Patients and controls

One hundred and one patients fulfilling at least four of the six European classification criteria for pSS were studied. ${ }^{9}$ HLA-DRBl typing, and both rheumatoid factor and IgG levels were tested routinely during clinical evaluation. Ro/La autoantibody screening was performed by counterimmunoelectrophoresis (CIE) and enzyme linked immunosorbent assay (ELISA) as previously described. ${ }^{1}$ The control group comprised 108 healthy South Australian volunteers to the Australian Bone Marrow Donor Registry.

\section{Fas polymorphism genotyping}

The $-1377 \mathrm{G} / \mathrm{A}$ and $-670 \mathrm{~A} / \mathrm{G}$ single nucleotide polymorphisms in the promoter of the Fas gene ${ }^{8}$ were genotyped using the polymerase chain reaction and sequence specific primers. Four combinations of sense primers, specific for $-1377 \mathrm{G} / \mathrm{A}$, and antisense primers, specific for $-670 \mathrm{G} / \mathrm{A}$, were used to directly amplify cis haplotypic combinations (table 1, fig 1).

\section{Statistics}

Exact tests for Hardy-Weinberg equilibrium, linkage disequilibrium and comparisons of Fas promoter genotype and allele frequencies were performed using Arlequin version 2.000 (http://anthro.unige.ch/arlequin). Associations between Fas promoter genotypes and IgG levels and rheumatoid factor titres were analysed by Kruskal-Wallis analysis of variance, and interaction between Fas promoter genotypes and HLA by Ro/La autoantibody status was analysed by logistic regression. These analyses were performed using Statistica, version 6.1 (StatSoft, Inc).

Abbreviations: CIE, counterimmunoelectrophoresis; ELISA, enzyme linked immunosorbent assay; pSS, primary Sjögren's syndrome 


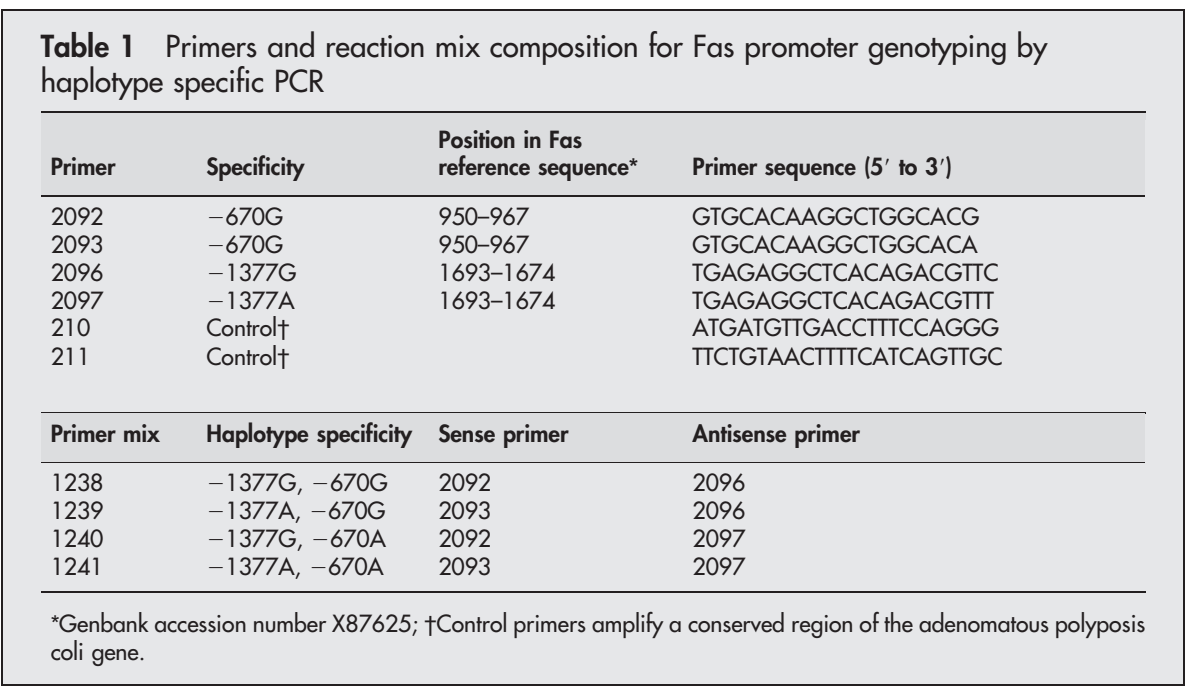

\section{RESULTS}

Table 2 summarises the Fas promoter -1377 and -670 genotype distributions and allele frequencies. No significant differences were observed between patients with pSS $(\mathrm{n}=101)$ and controls $(\mathrm{n}=108)$.

Patients with pSS were stratified into four groups according to increasing Ro/La autoantibody diversification ${ }^{2}$ : negative for anti-Ro/La autoantibodies $(\mathrm{n}=23)$; anti-Ro only $(\mathrm{n}=9)$; anti-Ro and non-precipitating $(\mathrm{ppt}-)$ anti-La (CIE negative, ELISA positive, $\mathrm{n}=19$ ); and anti-Ro and precipitating $(\mathrm{ppt}+)$ anti-La (CIE positive, $\mathrm{n}=50)$. No significant differences were seen in the Fas promoter polymorphisms between the three Ro/La autoantibody positive groups. Further, no associations were observed between Fas promoter polymorphisms and rheumatoid factor titre or serum IgG levels. However, the Fas $-670 \mathrm{~A}$ allele frequency was significantly increased in patients with Ro/La autoantibody negative pSS compared with patients with Ro/La autoantibody positive pSS ( $p=0.04$, table 2 ). As expected, ${ }^{2}$ HLA-DR2 and DR3 frequencies were increased in Ro/La autoantibody positive patients $(p=0.01)$, but HLA-DR and Fas -670 polymorphism effects were independent $(p=0.68)$.

\section{DISCUSSION}

Apoptosis may be important in the development of autoimmunity ${ }^{3}$ and the Fas-FasL pathway is one of the mediators of apoptosis. This study examined associations between polymorphisms in the promoter of the Fas gene and pSS, a systemic autoimmune disease.

It has been proposed that abnormal apoptosis in the exocrine glands of patients with pSS may have a role in glandular destruction, ${ }^{5}$ although this remains controversial. ${ }^{6}$ We found no associations between Fas promoter -1377 and -670 polymorphisms and pSS. This suggests that modulation of apoptosis by genetic variation in the Fas promoter is unlikely to be important in salivary gland destruction in most patients with pSS, and highlights the uncertainty and controversy about the role of sialoepithelial apoptosis as an initiating event in the pathogenesis of pSS.

Associations between clinical and immunological abnormalities are well recognised features of pSS. Patients with Ro/ La autoantibody negative pSS experience later onset, clinically milder disease with less glandular destruction. ${ }^{10}$ The Ro/La autoantibody categories used in this study represent stable subsets within a spectrum of diversification

Figure 1 Fas promoter genotyping by haplotype specific polymerase chain reaction (PCR). Four haplotype specific PCR reactions (table 1) were used to amplify cis combinations of the Fas promoter -1377 and -670 polymorphisms. Genomic DNA was amplified in $13 \mu$ l reaction mixtures consisting of $67 \mathrm{mM}$ Tris base $\mathrm{pH} 8.8 ; 16.6 \mathrm{mM}$ ammonium sulphate; $2 \mathrm{mM}$ magnesium chloride; $0.01 \% \mathrm{vol} / \mathrm{vol}$ Tween 20; $200 \mathrm{mM}$ of each of dATP, dTTP, dGTP, and dCTP; $0.1-0.01 \mu \mathrm{g}$ DNA; $3.4 \mathrm{mM}$ haplotype-specific primers, $6.8 \mathrm{mM}$ control primers; and 0.1875 units of Tag polymerase. Thermal cycling parameters were: 1 minute at $96^{\circ} \mathrm{C} ; 5$ cycles of $96^{\circ} \mathrm{C}$ for 25 seconds, $70^{\circ} \mathrm{C}$ for 45 seconds and $72^{\circ} \mathrm{C}$ for 45 seconds, followed by 21 cycles of $96^{\circ} \mathrm{C}$ for 25 seconds, $65^{\circ} \mathrm{C}$ for 50 seconds and $72^{\circ} \mathrm{C}$ for 45 seconds; followed by 4 cycles of $96^{\circ} \mathrm{C}$ for 25 seconds, $55^{\circ} \mathrm{C}$ for 60 seconds and $72^{\circ} \mathrm{C}$ for 120 seconds. PCR products were electrophoresed in $1.0 \%$ agarose gels containing $0.5 \mathrm{mg} / \mathrm{ml}$ ethidium bromide and visualised under ultraviolet illumination. Direction of electrophoresis is upward. 
Table 2 Fas promoter polymorphism frequencies by Ro/La autoantibody status in patients with pSS $v$ controls

\begin{tabular}{|c|c|c|c|c|c|c|c|}
\hline \multirow[b]{3}{*}{ Polymorphism } & & \multicolumn{4}{|c|}{ pSS Ro/La Status (No (\%)) } & \multirow{3}{*}{$\begin{array}{l}\text { All pSS } \\
(n=101)\end{array}$} & \multirow{3}{*}{$\begin{array}{l}\text { Controls } \\
(n=108)\end{array}$} \\
\hline & & \multirow{2}{*}{$\begin{array}{l}\text { Negative } \\
(n=23)\end{array}$} & \multirow{2}{*}{$\begin{array}{l}\text { Ro only } \\
(n=9)\end{array}$} & \multirow{2}{*}{$\begin{array}{l}\text { Ro+La (ppt-)* } \\
(n=19)\end{array}$} & \multirow{2}{*}{$\begin{array}{l}\text { Ro+La (ppt+)* } \\
(n=50)\end{array}$} & & \\
\hline & & & & & & & \\
\hline \multirow[t]{6}{*}{$\begin{array}{l}\text { Genotype distributions } 1 \\
\text { Fas }(-1377,-670) \pm\end{array}$} & G-A, G-A & $11(48)$ & $1(11)$ & $5(26)$ & $13(26)$ & $30(30)$ & $33(31)$ \\
\hline & $G-A, A-G$ & $4(17)$ & 1 (11) & 1 (5) & $5(10)$ & 11 (11) & $13(12)$ \\
\hline & $G-G, G-A$ & $6(26)$ & $6(67)$ & $10(53)$ & $21(42)$ & $43(43)$ & $41(38)$ \\
\hline & $A-G, A-G$ & $0(0)$ & $0(0)$ & $1(5)$ & $3(6)$ & $4(4)$ & $1(1)$ \\
\hline & $G-G, A-G$ & $0(0)$ & $0(0)$ & $0(0)$ & $3(6)$ & $3(3)$ & $6(6)$ \\
\hline & $G-G, G-G$ & $2(9)$ & $1(11)$ & $2(11)$ & $5(10)$ & $10(10)$ & $14(13)$ \\
\hline \multirow{3}{*}{ Fas -1377} & GG & 19 (83) & $8(89)$ & $17(89)$ & $39(78)$ & $83(82)$ & $88(82)$ \\
\hline & GA & $4(17)$ & $1(11)$ & $1(5)$ & $8(16)$ & $14(14)$ & $19(18)$ \\
\hline & AA & $0(0)$ & $0(0)$ & $1(5)$ & $3(6)$ & $4(4)$ & $1(1)$ \\
\hline \multirow[t]{3}{*}{ Fas -670} & GG & $2(9)$ & $1(11)$ & $3(16)$ & 11 (22) & $17(17)$ & $21(19)$ \\
\hline & GA & $10(43)$ & $7(78)$ & 11 (58) & $26(52)$ & $54(53)$ & $54(50)$ \\
\hline & AA & $11(48)$ & $1(11)$ & $5(26)$ & $13(26)$ & $30(30)$ & $33(31)$ \\
\hline \multirow{4}{*}{$\begin{array}{l}\text { Allele frequencies } \\
\text { Fas }(-1377,-670) \neq\end{array}$} & & & & & & & \\
\hline & G-A & 0.696 & 0.500 & 0.553 & 0.520 & 0.564 & 0.556 \\
\hline & $G-G$ & 0.217 & 0.444 & 0.368 & 0.340 & 0.327 & 0.347 \\
\hline & $A-G$ & 0.087 & 0.056 & 0.079 & 0.140 & 0.109 & 0.097 \\
\hline \multirow[t]{2}{*}{ Fas -1377} & G & 0.913 & 0.944 & 0.921 & 0.860 & 0.891 & 0.903 \\
\hline & A & 0.087 & 0.056 & 0.079 & 0.140 & 0.109 & 0.097 \\
\hline \multirow[t]{2}{*}{ Fas -670} & $A$ & $0.696 \S$ & 0.500 & 0.553 & 0.520 & 0.564 & 0.556 \\
\hline & G & 0.304 & 0.500 & 0.447 & 0.480 & 0.436 & 0.444 \\
\hline
\end{tabular}

of Ro/La responses. This diversification appears to be largely under genetic control, and the HLA class II associations and clinical features of these autoantibody subsets have previously been reported. ${ }^{12}$ Because the normally intracellular Ro and La autoantigens are concentrated within surface blebs of apoptotic cells, ${ }^{7}$ a potential source of autoantigens, we suggested that Fas promoter polymorphisms may influence Ro/La autoantibody status in pSS. We found no differences in Fas -1377 or -670 promoter polymorphisms between the three Ro/La autoantibody positive pSS subgroups (table 2), but the $-670 \mathrm{~A}$ allele frequency was significantly increased in Ro/La autoantibody negative patients compared with Ro/La autoantibody positive patients $(p=0.04)$, an effect independent of HLA class II.

The Fas -670A allele has been implicated in other rheumatic diseases such as rheumatoid arthritis ${ }^{11}$ and systemic lupus erythematosus. ${ }^{12}$ There are two explanations for the observed association between the Fas -670A allele and Ro/La autoantibody negative pSS found in this study. Possibly, the level of activity of the Fas apoptotic pathway influences Ro/La autoantibody positivity independently of factors conferring disease susceptibility to pSS. Alternatively, patients with Ro/La autoantibody negative pSS may be a heterogeneous subgroup with differences in underlying pathogenesis.

Two prior studies have examined polymorphisms in the Fas gene in pSS. Bertolo et al reported no associations with coding polymorphisms, but the promoter was not examined..$^{13}$ Bolstad et al reported a modest increase in the frequency of the $-670 \mathrm{G}$ allele in Norwegian patients with pSS (not confirmed in this study of Australian patients with pSS), but associations with Ro/La autoantibody status were not investigated..$^{14}$ This discrepancy between the two studies may be due to genetic differences between Australian and Norwegian populations, although the control group Fas promoter polymorphism frequencies were comparable.
Alternatively, there may be differences between the pSS patient groups. Both studies used the same classification criteria for pSS, ${ }^{9}$ but only $33 \%$ of patients with pSS were positive for Ro/La autoantibodies in the Norwegian study compared with $77 \%$ in the current study.

In summary, we found no association between Fas promoter polymorphisms and pSS. Within patients with pSS, the $-670 \mathrm{~A}$ allele frequency was increased in those who were Ro/La autoantibody negative compared with Ro/La autoantibody positive patients, suggesting a possible protective effect of this allele on the development of Ro/La autoantibodies in patients with pSS. Evaluation of associations between Fas promoter polymorphisms and other less well characterised autoantibodies in pSS, such as anti-fodrin and anti-M3 muscarinic receptor, will be of potential interest, as these autoantigens also relocate to surface blebs during apoptosis. ${ }^{15}$ Other polymorphic genes which influence apoptosis include FasL, bcl-2, bcl- $x$, tumour necrosis factor receptor, tumour necrosis factor, and several other cytokines, and further study of the genetics of apoptosis in pSS is warranted.

\section{ACKNOWLEDGEMENTS}

Many thanks to the Arthritis Foundation of South Australia Lupus/ Scleroderma/Sjögren's Support Group and the patients with Sjögren's syndrome who took part in this study. Many thanks to Dr Sara Marshall for provision of primer sequences for Fas genotyping.

\section{Authors' affiliations}

C G Mullighan, P G Bardy, Haematology, Institute of Medical and Veterinary Science, Adelaide, Australia

S Heatley, Research and Development, Australian Red Cross Blood Service, Adelaide, Australia

S Lester, M Rischmueller, Department of Rheumatology, The Queen Elizabeth Hospital, Woodville, Australia 
T P Gordon, Department of Immunology, Allergy and Arthritis, Flinders Medical Centre, Bedford Park, Australia

Support and financial interests: none.

Correspondence to: $\operatorname{Dr}$ C G Mullighan, Department of Haematology, Institute of Medical and Veterinary Science, PO Box 14, Rundle Mall, SA, 5000, Australia; cmull@senet.com.au

Accepted 28 April 2003

\section{REFERENCES}

1 Beer RG, Rischmueller M, Coates T, Purcell AW, Keech CL, McCluskey J, et al. Nonprecipitating anti-La(SS-B) autoantibodies in primary Sjögren's syndrome. Clin Immunol Immunopathol 1996;79:314-18.

2 Rischmueller M, Lester S, Chen Z, Champion G, Van Den Berg R, Beer R, et al. HLA class II phenotype controls diversification of the autoantibody response in primary Siögren's syndrome (pSS). Clin Exp Immunol 1998; 1 11:365-71.

3 Ogawa N, Dang H, Talal N. Apoptosis and autoimmunity. J Autoimmun 1995;8:1-19.

4 Skarstein K, Nerland AH, Eidsheim M, Mountz JD, Jonsson R. Lymphoid cell accumulation in salivary glands of autoimmune MRL mice can be due to impaired apoptosis. Scand J Immunol 1997;46:373-8.

5 Manganelli P, Quaini F, Andreoli AM, Lagrasta C, Pilato FP, Zuccarelli A, et al. Quantitative analysis of apoptosis and bcl-2 in Siögren's syndrome. J Rheumatol 1997;24:1552-7.

6 Ohlsson M, Skarstein K, Bolstad Al, Johannessen AC, Jonsson R. Fas-induced apoptosis is a rare event in Sjögren's syndrome. Lab Invest 2001;81:95-105.
7 Ohlsson M Jonsson R, Brokstad KA. Subcellular redistribution and surface exposure of the Ro52, Ro60 and La48 autoantigens during apoptosis in human ductal epithelial cells: a possible mechanism in the pathogenesis of Siögren's syndrome. Scand J Immunol 2002;56:456-69.

8 Huang QR, Morris D, Manolios N. Identification and characterization of polymorphisms in the promoter region of the human Apo-1/Fas (CD95) gene. Mol Immunol 1997;34:577-82.

9 Vitali C, Bombardieri S, Moutsopoulos HM, Balestrieri G, Bencivelli W, Bernstein RM, et al. Preliminary criteria for the classification of Siögren's syndrome. Results of a prospective concerted action supported by the European Community. Arthritis Rheum 1993;36:340-7.

10 Halse A, Wahren-Herlenius M, Jonsson R. Ro/SS-A- and La/SS-B-reactive B lymphocytes in peripheral blood of patients with Sjögren's syndrome. Clin Exp Immunol 1999:115:208-13.

11 Huang QR, Danis V, Lassere M, Edmonds J, Manolios N. Evaluation of a new Apo-1/Fas promoter polymorphism in rheumatoid arthritis and systemic lupus erythematosus patients. Rheumatology (Oxford), 1999;38:645-51.

12 Kanemitsu S, Ihara K, Saifddin A, Otsuka T, Takeuchi T, Nagayama J, et al. A functional polymorphism in fas (CD95/APO-1) gene promoter associated with systemic lupus erythematosus. J Rheumatol 2002;29:1183-8.

13 Bertolo F, De Vita S, Dolcetti R, Carbone A, Ferraccioli GF, Bartoli E, et al. Lack of Fas and Fas-L mutations in patients with lymphoproliferative disorders associated with Sjögren's syndrome and type II mixed cryoglobulinemia. Clin Exp Rheumatol 1999;17:339-42.

14 Bolstad AI, Wargelius A, Nakken B, Haga HJ, Jonsson R. Fas and Fas ligand gene polymorphisms in primary Siögren's syndrome. J Rheumatol 2000;27:2397-405.

15 Nagaraju K, Cox A, Casciola-Rosen L, Rosen A. Novel fragments of the Siögren's syndrome autoantigens alpha-fodrin and type 3 muscarinic acetylcholine receptor generated during cytotoxic lymphocyte granuleinduced cell death. Arthritis Rheum 2001;44:2376-86. 